\title{
PARTISIPASI MASYARAKAT DALAM PengelolaAn Wilayah Pesisir di ACEH
}

Safrina ${ }^{1}$

\begin{abstract}
Abstrak
Partisipasi masyarakat dalam perlindungan dan pengelolaan lingkungan hidup telah menjadi agenda negara-negara di dunia terutama setelah menjadi salah satu prinsip dalam Deklarasi Rio 1992. Indonesia melalui Undang-Undang Nomor 32 Tahun 2009 tentang Perlindungan dan Pengelolaan Lingkungan Hidup mencantumkan prinsip partisipatif sebagai salah satu asas dalam penyusunan setiap kebijakan terkait lingkungan hidup. Tulisan ini bertujuan untuk memaparkan pelaksanaan Program Pengelolaan Wilayah Laut Berbasis masyarakat pada Masyarakat Ujong Pancu, Kabupaten Aceh Besar dan memahami bagaimana peran institusi adat laot (Panglima Laot) dalam pengelolaan lingkungan pesisir. Perlindungan dan pengelolaan wilayah pesisir di Aceh dilakukan dengan menggunakan dua pendekatan, yaitu melalui pembentukan aturan hukum yang mendukung dan penguatan kapasitas institusi masyarakat, institusi adat dan hukum adat yang dipercaya dapat menjadi wadah yang efektif untuk melibatkan masyarakat dalam proses pembangunan. Melalui program tersebut masyarakat terlibat secara langsung dalam penentuan kawasan konservasi laut dan juga ikut menentukan langkah-

\footnotetext{
1 Safrina, S.H., M.H., M.EPM mendapatkan gelar sarjana dan master hukum dari Universitas Syah Kuala, dan Master of Environmental Policy and Management dari University of Adelaide, South Australia. Sekarang Penulis merupakan Staff Pengajar di Fakultas Hukum Universitas Syiah Kuala, Nanggroe Aceh Darussalam, mengajar mata kuliah Hukum Dagang, Hukum Perusahaan, Hukum Jaminan, Hukum Surat Berharga, dan Hukum Lingkungan.
} 
langkah yang terbaik untuk melindungi kawasan pesisir tempat mereka menetap. Lebih lanjut, melalui pengelolaan wilayah pesisir berbasis masyarakat dapat meminimalkan dampak negatif dari pembangunan dan memungkinkan masyarakat untuk memperoleh informasi yang berimbang dan obyektif sehingga dapat memberikan kontribusi untuk pemecahan masalah-masalah lingkungan.

Kata Kunci: Partisipasi masyarakat, perlindungan dan pengelolaan lingkungan hidup

\begin{abstract}
Community participation in protection and management of the environment has been on the agenda of countries in the world, especially after incorporated as a principle in the Rio Declaration of 1992. Indonesia, through Law No. 32 of 2009 on the Environmental Protection and Management included participatory principle in policy-making related to the environment. This study aims to examine the implementation of community participation in coastal management and to analyze the role of adat institution (Panglima Laot) in managing the coastal environment in Aceh. Protection and management of coastal areas in Aceh is conducted under two approaches, namely the establishment of the regulations that support the implementation process and strengthening the capacity of public institutions; and traditional institutions and customary laws that are believed can be an effective way to engage community in the development process. Through a program of community-based coastal management, community directly involved in determining the marine conservation areas and also determine the best steps to protect their region. Moreover, the program can also minimize the negative impacts of development and enable public to obtain a balanced and objective information that can contribute to solve the problems in their environment.
\end{abstract}

Key words: community participation, protection and management of the environment

\title{
1. Pendahuluan
}

Provinsi Aceh terletak di ujung barat Pulau Sumatera, Indonesia, yang dibatasi oleh Selat Malaka di sebelah timur dan Samudera Hindia di sebelah barat. Wilayah perairan Aceh merupakan salah satu yang 
terbesar di Indonesia dan didominasi oleh ekosistem terumbu karang yang berperan sangat signifikan terhadap keberlangsungan habitat laut dan masyarakat pesisir. Terumbu karang berfungsi sebagai pelindung pantai dari abrasi dan menjadi tempat habitat laut memperoleh makanan, sehingga fungsinya perlu dilestarikan. Di lain pihak, tekanan antropogenik (aktivitas manusia) diduga berkontribusi terhadap rusaknya ekosistem wilayah pesisir. Makin banyak terumbu karang yang penting bagi keberlanjutan kehidupan ekosistem pantai yang rusak karena maraknya penggunaan alat tangkap yang tidak ramah lingkungan, seperti potasium, bom, dan pukat harimau (trawl). Berdasarkan survey pendataan terumbu karang tahun 2008 hingga tahun 2010, tercatat dari 91 lokasi yang disurvey, hanya 14 lokasi yang terumbu karangnya masih dalam kondisi baik. ${ }^{2}$ Selain disebabkan oleh aktivitas manusia, kerusakan terumbu karang di wilayah Aceh juga disebabkan oleh faktor alam seperti tsunami, naiknya suhu permukaan laut dan pemutihan terumbu karang yang salah satunya disebabkan oleh perubahan iklim akibat pemanasan global.

Partisipasi masyarakat, selain menunjukkan negara mengakui pentingnya peran masyarakat dalam pengelolaan lingkungan, juga berupaya untuk meningkatkan kualitas kebijakan pemerintah terkait lingkungan hidup ${ }^{3}$ sehingga manfaatnya dapat dirasakan oleh masyarakat. Di samping itu, keterlibatan masyarakat juga dianggap penting karena masyarakat merupakan pihak yang paling rentan terhadap dampak yang ditimbulkan oleh kerusakan lingkungan sehingga bagi masyarakat konsep ini dianggap sebagai wujud dari partisipasi dalam proses pembangunan. Partisipasi juga merupakan upaya untuk meminimalkan dampak negatif pembangunan, khususnya pembangunan yang berhubungan secara langsung dengan masyarakat dan lingkungan tempat mereka menetap. ${ }^{4}$ Lebih lanjut, keterlibatan masyarakat dalam pembangunan dapat menjadi salah satu solusi dalam mengatasi dampak

2 Aceh Ocean Coral, Formasi Terumbu Karang Aceh, http://acehoceancoral.org/artikel/formasi-terumbu-karang-aceh, diakses pada tanggal 28 Februari 2014.

3 Muhammad Akib, Politik Hukum Lingkungan: Dinamika dan Refleksinya dalam Produk Hukum Otonomi Daerah, (Jakarta: RajaGrafindo Persada, 2012), hal. 124.

4 Kim A. Johnston, "Community Engagement: A Relational Perspective", dalam Tebbutt, Cregan, and Kate (Editor), (Prosiding dalam Australia and New Zealand Communication Association Annual Conference, 2007). 
sosial dari pembangunan dan dapat meningkatkan kualitas kebijakan dan program terkait lingkungan. ${ }^{5}$

Prinsip pembangunan partisipatif pertama kali diperkenalkan dalam Deklarasi Rio 1992 tentang Lingkungan dan Pembangunan yang menyebutkan tentang pentingnya mengedepankan partisipasi masyarakat dalam penyelesaian masalah-masalah lingkungan. Selengkapnya Prinsip 10 Deklarasi Rio menyatakan,

"Environmental issues are best handled with the participation of all concerned citizens, at the relevant level. At the national level, each individual shal have appropriate access to information concerning the environment that is held by public authorities, including information on hazardous materials and activities in their communities, and the opportunity to participate in decisionmaking processes. States shall facilitate and encourage public awareness and participation by making information widely available. Effective access to juducial and administrative proceedings, including redress and remedy, shall be provided."

Kebijakan dan program pemerintah terutama yang terkait dengan isu lingkungan, akan lebih efektif diterapkan jika melibatkan banyak pihak termasuk masyarakat. Hal ini disebabkan sifat dari lingkungan yang membentuk suatu ekosistem yang terkait antara satu dengan yang lain. Selanjutnya, negara bertanggung jawab untuk membuat dan menyediakan prosedur dan mekanisme yang memungkinkan masyarakat terlibat dalam pembangunan dan menjadi bagian dari proses pembangunan.

Indonesia melalui Undang-Undang Nomor 32 Tahun 2009 tentang Perlindungan dan Pengelolaan Lingkungan hidup ("UUPPLH") mengakui penerapan prinsip pembangunan partisipatif sebagai salah satu asas dalam pengelolaan lingkungan dalam Pasal 2 huruf k. ${ }^{7}$ Dalam penjelasan Pasal 2 huruf $k$ disebutkan bahwa "setiap anggota masyarakat didorong untuk berperan aktif dalam proses pengambilan keputusan dan pelaksanaan perlindungan dan pengelolaan lingkungan hidup, baik

5 Reed, "Stakeholder Participation for Environmental Management: A Literature Review," Biological Conservation, Vol. 141 (2008), hal. 2426.

6 Indonesia, Undang-Undang tentang Perlindungan dan Pengelolaan Lingkungan Hidup (“UUPPLH”), No. 32 Tahun 2009, Lembaran Negara Tahun 2009 No.140, Tambahan Lembaran Negara No. 5059.

7 Pasal 2 huruf k UUPPLH, Ibid. 
secara langsung maupun tidak langsung."8 Selanjutnya Pasal 70 ayat (1) mengatur bahwa masyarakat memiliki hak dan kesempatan yang sama dan seluas-luasnya untuk berperan aktif dalam perlindungan dan pengelolaan lingkungan hidup. ${ }^{9}$ Adapun bentuk peran masyarakat tersebut dijelaskan dalam ayat (2) yaitu: (a) pengawasan sosial, (b) pemberian saran, pendapat, usul, keberatan, pengaduan, dan/atau, (c) penyampaian informasi dan/ atau laporan. ${ }^{10}$ Dalam penjelasan Pasal 70 disebutkan bahwa pemberian saran, pendapat dan usul diantaranya dalam penyusunan Kajian Lingkungan Hidup Strategis (KLHS) dan Analisis Mengenai Dampak Lingkungan (AMDAL). ${ }^{11}$

Dalam kaitannya dengan masyarakat pesisir, Undang-Undang Nomor 27 Tahun 2007 tentang Pengelolaan Daerah Pesisir (UU Pengelolaan Daerah Pesisir) ${ }^{12}$ mengakui hak, kewajiban dan peran serta masyarakat dalam pengelolaan wilayah pesisir. Pasal 62 ayat (1) mengatur bahwa "masyarakat mempunyai kesempatan yang sama untuk berperan serta dalam perencanaan, pelaksanaan, dan pengawasan terhadap pengelolaan wilayah pesisir dan pulau-pulau kecil."13 Selanjutnya ayat (2) mengatur bahwa "ketentuan mengenai peran serta masyarakat dalam pengelolaan wilayah pesisir akan diatur lebih lanjut dalam Peraturan Menteri."14 Sampai tulisan ini ditulis, belum ada peraturan menteri yang mengatur peran masyarakat dalam pengelolaan wilayah pesisir, sehingga belum ada acuan yang jelas bagaimana bentuk peran serta masyarakat dalam pengelolaan wilayah pesisir.

Di tengah ketiadaan peraturan pelaksana terkait peran serta masyarakat dalam perlindungan wilayah pesisir, Pemerintah Aceh melaksanakan program pengelolaan wilayah pesisir berbasis masyarakat yang merupakan kerjasama antara Dinas Kelautan dan Perikanan ("DKP") Provinsi Aceh dan Flora Fauna Indonesia (FFI), yang salah satunya terdapat di Desa Ujong Pancu, Kabupaten Aceh Besar.

8 Ibid.

9 Pasal 70 ayat (1) UUPPLH, Ibid.

10 Pasal 70 ayat (2) UUPPLH, Ibid.

11 Ibid.

12 Indonesia, Undang-Undang tentang Pengelolaan Daerah Pesisir, UU No. 27 Tahun 2007, Lembaran Negara Tahun 2007 No. 84, Tambahan Lembaran Negara No. 4739; Lihat juga Indonesia, Undang-Undang tentang Perubahan atas UndangUndang No. 27 Tahun 2007 tentang Pengelolaan Wilayah Pesisir dan Pulau-pulau Kecil, UU No. 1 Tahun 2014, Lembaran Negara Tahun 2014 No. 2, Tambahan Lembaran Negara No. 5490.

13 Pasal 62 ayat (1) UU Pengelolaan Daerah Pesisir, Ibid.

14 Pasal 62 ayat (2) UU Pengelolaan Daerah Pesisir, Ibid. 
Berdasarkan hal tersebut, artikel ini bertujuan untuk memaparkan pelaksanaan Program Pengelolaan Wilayah Laut Berbasis Masyarakat pada masyarakat Ujong Pancu dan memahami bagaimana peran institusi adat laot (Panglima Laot) dalam pengelolaan lingkungan pesisir.

\section{Masyarakat dan Keterlibatan Masyarakat dalam Perlindungan dan Pengelolaan Lingkungan}

Meningkatnya pemahaman tentang pentingnya keterlibatan masyarakat dalam pembangunan telah memunculkan diskusi tentang pengertian masyarakat dan keterlibatan masyarakat. Masyarakat berasal dari kata latin communis, yang berarti "umum, publik, dan yang dibagi dengan banyak pihak." Menurut Sarkissian, memberikan adalah "kelompok yang berbagi wilayah, kepentingan atau kegiatan yang ditandai oleh pola interaksi antar individu, persepsi terhadap kesamaan atau kepentingan bersama dan geografi."15 Menurut pengertian ini, masyarakat diartikan sebagai sekelompok orang yang memiliki ikatan asal usul leluhur dan geografis yang sama, dan umumnya juga dikaitkan dengan hukum (termasuk hukum adat) yang menjadi norma yang mengikat masyarakat tersebut, contohnya masyarakat perkotaan, masyarakat pedesaan, masyarakat Indonesia, atau bisa dipahami bahwa pengertian ini melihat masyarakat dalam komunitas yang kecil sampai masyarakat dunia, yang semuanya berinteraksi berdasarkan kesamaan kepentingan dan wilayah.

Pengertian lain dikemukan oleh Connor, yang mendefinisikan masyarakat sebagai "people living in a place, who develop a sense of identity and a common culture, and who create interdependence in a social system."16 Menurut pengertian ini masyarakat dipandang sebagai sekelompok orang-orang yang memiliki kesamaan ide dan aktifitas bersama yang berkumpul untuk mencapai tujuan yang sama. ${ }^{17}$ Dalam kaitannya dengan pengelolaan lingkungan, masyarakat yang dimaksud termasuk

15 Penulis menerjemahkan bebas dari bahasa asli, "Any group that shares a location, interests or practices, defined by patterns of interaction among individuals, perception of commonality or common interest and geography." Sarkissian, et al, Kitchen Table Sustainability: Practical Recipes for Community Engagement with Sustainability, (UK: Earthscan, 2009).

16 Ibid.

17 Connor dalam Sarkissian, et al, Kitchen Table Sustainability: Practical Recipes For Community Engagement With Sustainability, (UK: Earthscan, 2009). 
diantaranya Lembaga Swadaya Masyarakat ("LSM") nasional atau internasional yang peduli dengan isu-isu lingkungan.

UUPPLH tidak memberikan definisi apa yang dimaksud dengan masyarakat, akan tetapi memberikan definisi masyarakat hukum adat yaitu "kelompok masyarakat yang secara turun termurun bermukim di wilayah geografis tertentu karena adanya ikatan pada asal usul leluhur, adanya hubungan yang kuat dengan lingkungan hidup, serta adanya sistem nilai yang menentukan pranata ekonomi, politik sosial, dan hukum."18 Pengertian masyarakat dapat ditemukan dalam UU Pengelolaan Daerah Pesisir, yang membagi masyarakat ke dalam masyarakat adat, masyarakat lokal, dan masyarakat tradisional, yang definisinya adalah sebagai berikut:

“Masyarakat adat adalah kelompok masyarakat pesisir yang secara turun temurun bermukim di wilayah geografis tertentu karena adanya ikatan pada asal usul leluhur, adanya hubungan yang kuat dengan sumber daya pesisir dan pulau-pulau kecil, serta adanya sistem nilai yang menentukan pranata ekonomi, politik, sosial dan hukum."19

“Masyarakat lokal didefinisikan sebagai kelompok masyarakat yang menjalankan tata kehidupan sehari-hari berdasarkan kebiasaan yang sudah diterima sebagai nilainilai yang berlaku umum tetapi tidak sepenuhnya bergantung pada sumber daya pesisir dan pulau-pulau kecil tertentu." 20

“Masyarakat tradisional adalah masyarakat perikanan tradisional yang masih diakui hak tradisionalnya dalam melakukan kegiatan penangkapan ikan atau kegiatan lainnya yang sah didaerah-daerah tertentu yang berada dalam perairan kepulauan sesuai dengan kaidah hukum laut internasional." 21

Berdasarkan pengertian tersebut dapat disimpulkan bahwa UU Pengelolaan Daerah Pesisir mendefinisikan masyarakat sebagai: (1) sekelompok orang yang berkumpul dalam satu wilayah karena adanya kesamaan adat istiadat dan nilai-nilai yang dipercaya sebagai norma

\footnotetext{
18 Pasal 1 angka 31 UUPPLH, Op. Cit.

19 Pasal 1 angka 33 UU Pengelolaan Daerah Pesisir, Op. Cit.

20 Pasal 1 angka 34 UU Pengelolaan Daerah Pesisir, Ibid.

${ }^{21}$ Pasal 1 angka 35 UU Pengelolaan Daerah Pesisir, Ibid.
} 
dimana kelompok tersebut menggantungkan hidupnya dari hasil laut; (2) sekelompok orang yang tinggal diwilayah pesisir tetapi tidak menggantungkan hidupnya pada hasil laut. Yang menarik adalah adanya pemisahaan antara masyarakat adat dan masyarakat tradisional, yang jika dipahami memiliki arti yang sama yaitu kesamaan wilayah akan tetapi ada penambahan pengakuan terhadap hukum laut internasional pada kelompok masyarakat tradisional. Walaupun terdapat perbedaan dalam mendefinisikan masyarakat, dan tidak ada pengertian yang universal menyangkut konsep tersebut, ${ }^{22}$ akan tetapi dalam kaitannya dengan peran masyarakat dalam pengelolaan lingkungan, partisipasi kedua tipe masyarakat menjadi penting dan saling mendukung.

Sementara itu, keterlibatan masyarakat dianggap sebagai "proses keterlibatan dimana sekelompok orang bekerja bersama untuk mencapai tujuan yang sama dengan komitmen untuk sejumlah nilai, prinsip, dan kriteria."23 Partisipasi masyarakat diharapkan dapat dilakukan secara aktif dengan mekanisme keterlibatan yang diatur oleh pemerintah. Selanjutnya, diperlukan peranan pengambil kebijakan untuk menyediakan aturan hukum bagi keterlibatan masyarakat tersebut.

Partisipasi masyarakat dianggap sebagai salah satu langkah demokratis dalam menciptakan kebijakan yang lebih efektif, responsif, dan informatif, dan juga dapat mengembangkan aspek psikologi dan pendidikan dalam pembangunan masyarakat dan individu.24 Konsep keterlibatan masyarakat telah berkembang dalam berbagai pendekatan. Salah satu yang mengundang perhatian adalah keterlibatan masyarakat dalam pengelolaan hutan (community-based forest management) yang diperkenalkan oleh Elinor Ostrom. ${ }^{25}$ Ostrom menyatakan bahwa keterlibatan masyarakat dalam pengelolaan hutan dianggap penting

22 Terjemahan bebas Penulis dari "engagement processes and practices in which a wide range of people work together to achieve a share goal guided by a commitment to a common set of values, principles, and criteria." Warburton, $A$ Passionate Dialogue: Community and Sustainable Development, 1998, dalam Warburton, Community and Sustainable Development: Participation in the future, (UK: Earthscan, 1998).

23 Aslin dan Brown, Towards Whole of Community Engagement: A Practical Toolkit, (South Australia: Murray Darling Basin Commission, 2004) hal. 3.

24 Dakin, "Challenging Old Models of Knowledge and learning: New Perspective for Participation in Environmental Management and Planning," Environments, Vol.31, No.1, (2003), hal. 94.

${ }^{25}$ Ostrom, "Self-Governance and Forest Resources", (Occasional Paper No. 20, Centre for International Forestry Research, Bogor, Indonesia, 1999). 
karena sifat dari sumber daya hutan yang memiliki fungsi ekonomi, sosial, dan lingkungan. Oleh sebab itu, pengelolaan wilayah hutan idealnya juga melibatkan masyarakat karena masyarakat yang tinggal di sekitar hutan masih sangat tergantung pada manfaat hutan untuk memenuhi kebutuhan hidup. Situasi tersebut diistilahkan oleh Ostrom sebagai "common-pool resources." Dalam perkembangannya, teori modern dari "common-pool" menyimpulkan bahwa keterlibatan berbagai pihak (governance system) penting dalam pengelolaan sumber daya alam untuk menghindari terjadinya eksploitasi sumber daya alam yang berdampak pada rusaknya sumber alam dan menghilangkan fungsinya sebagai salah satu komponen ekosistem yang saling terkait dengan komponen lainnya.

Pengelolaan daerah pesisir juga mempunyai tantangan yang sama, karena ekosistem laut memiliki manfaat ekonomi bagi masyarakat pesisir di samping fungsinya sebagai pelindung kelestarian wilayah tersebut. Salah satu program yang dikembangkan dalam upaya pengelolaan wilayah peisir adalah penetapan kawasan perlindungan wilayah laut (Marine Protected Area, selanjutnya disebut "MPA") dengan melibatkan masyarakat sebagai aktor utama. ${ }^{26}$ Terdapat 2 (dua) faktor yang mendasari pelaksanaan MPA, yaitu konservasi (conservation) dan solidaritas (solidarity). Konservasi dimaksudkan sebagai tindakan perlindungan kehidupan laut demi menjaga ekosistem laut dengan mempertahankan cara-cara yang ramah lingkungan dan juga melindungi kepentingan ekonomi masyarakat yang berkepentingan. Sedangkan solidaritas dimaksudkan sebagai kemauan untuk mewujudkan kebijakan konservasi melalui sebuah mekanisme yang institusional yang melibatkan banyak pihak (stakeholders), dimana proses tersebut dilakukan dengan memperhatikan faktor-faktor sosial, budaya dan ekonomi. ${ }^{27}$

Manajemen bersama (co-management) merupakan model kebijakan yang memberikan peluang kepada masyarakat untuk berpartisipasi dalam proses pembangunan, termasuk dalam program dan kebijakan terkait pengelolaan lingkungan. Model kebijakan ini juga merupakan pendekatan yang potensial untuk mempromosikan konsep manajemen partisipatif dan kolaboratif dengan menekankan pada berbagai tingkat

26 Oracion, Miller, dan Christie, "Marine Protected Areas For Whom? Fisheries, Tourism, And Solidarity In Philippine Community", Ocean and Coastal Management, Vol. 48, (2005), hal. 394, dan Tullungan, Kussoy, dan Crawford, "Community Based Coastal Resources Management In Indonesia: North Sulawesi Early Stage Experiences", (Makalah disampaikan dalam Convention of Integrated Coastal Management Practitioners in the Philippines, 1998), hal. 2.

27 Oracion, Miller, dan Christie, op.cit., hal. 394-395. 
keterlibatan untuk mencapai tujuan yaitu perlindungan keanekaragaman hayati dan pengakuan terhadap eksistensi budaya masyarakat lokal. Selain itu, manajemen bersama juga dapat mencerminkan kekuatan hubungan antara para pihak. ${ }^{28}$

\section{Pengaturan tentang Partisipasi Masyarakat dalam Pengelolaan Wilayah Pesisir di Provinsi Aceh}

Di Provinsi Aceh, peran masyarakat dalam pengelolaan dan perlindungan lingkungan diatur dalam beberapa Qanun, diantaranya Qanun Nomor 16 Tahun 2002 tentang Pengelolaan Sumber Daya Kelautan dan Perikanan ("Qanun Pengelolaan Sumber Daya Kelautan dan Perikanan") dan Qanun Nomor 2 Tahun 2011 tentang Pengelolaan Lingkungan Hidup (“Qanun Pengelolaan Lingkungan Hidup”).

Peran masyarakat diatur dalam Pasal 9 ayat (1) Qanun Pengelolaan Lingkungan Hidup yang menyebutkan bahwa "Masyarakat memiliki kesempatan yang seluas-luasnya untuk berperan aktif dalam pengelolaan lingkungan hidup." Selanjutnya, ayat (2) mengatur bahwa keterlibatan tersebut diantaranya dapat dilakukan dalam bentuk: (a) pengelolaan jasa lingkungan; (b) pengurangan risiko bencana; (c) pengawasan sosial; (d) pemberian saran, pendapat, usul, keberatan, pengaduan; (e) penyampaian informasi atau laporan; dan/atau (f) partisipasi aktif masyarakat dalam penyelamatan lingkungan hidup. Lebih lanjut, ayat 3 mengatur bahwa peran masyarakat bertujuan untuk, antara lain: (a) meningkatkan kepedulian dalam pengelolaan lingkungan hidup; (b) meningkatkan kemandirian, keberdayaan masyarakat dan kemitraan; (c) menumbuhkembangkan kemampuan dan kepeloporan masyarakat; (d) menumbuhkembangkan ketanggapsegeraan masyarakat untuk melakukan pengawasan sosial; (e) mengembangkan dan menjaga budaya dan kearifan lokal dalam rangka pelestarian fungsi lingkungan hidup; dan (f) meningkatkan kesejahteraan masyarakat melalui pengelolaan jasa lingkungan. Walaupun qanun mengakui partisipasi aktif masyarakat dalam pengelolaan lingkungan hidup, namun prinsip partisipatif sendiri

28 Nursey-Bray, Rist, “Co-management and protected area management: Achieving effective management of a contested site, lessons from the Great Barrier Reef World Heritage Area(GBRWHA)", Marine Policy, Vol. 33, (2009), hal. 118-127, dan Hill, “Towards Equity In Indigenous Co-Management Of Protected Areas: Cultural Planning By Miriuwung-Gajerrong People In The Kimberley, Western Australia", Geographical Research, Vol. 49(10), (2011), hal. 72-85. 
tidak disebutkan sebagai salah satu prinsip yang menjadi landasan pengaturan pengelolaan lingkungan berdasarkan qanun tersebut.

Sedangkan dalam Qanun Pengelolaan Sumber Daya Kelautan dan Perikanan, tidak ada pasal yang khusus mengatur tentang peran masyarakat. Pasal 19 ayat (1) memandatkan "penyelenggaraan konservasi sumber daya kelautan dan perikanan melibatkan pula partisipasi aktif masyarakat nelayan dan pihak terkait lainnya." Tidak ada penjelasan lebih lanjut tentang bagaimana wujud dari partisipasi masyarakat tersebut dan apakah akan diatur tersendiri dalam peraturan pelaksanaan. Qanun tersebut juga mengakui keberadaan lembaga adat dalam pengelolaan sumber daya perikanan sebagaimana yang diatur dalam Pasal 11 ayat (1) yang menyebutkan bahwa "Dalam pengelolaan sumber daya perikanan, Pemerintah Provinsi mengakui keberadaan Panglima Laot dan hukum adat laot yang telah ada dan eksis dalam kehidupan masyarakat nelayan. Pengakuan ini memperkuat keberadaan institusi adat dan hukum adat di tengah pro dan kontra terkait keberadaan dan perannya yang terus berubah dan berkembang seiring dengan perubahan masyarakat." 29

Lembaga adat Panglima Laot mendapat pengakuan secara hukum melalui Undang-Undang No. 11 Tahun 2006 tentang Pemerintahan Aceh ("UUPA"), Qanun Nomor 10 Tahun 2008 tentang Lembaga Adat ("Qanun Lembaga Adat"), dan Qanun Nomor 9 Tahun 2008 tentang Pembinaan Kehidupan Adat dan Adat Istiadat ("Qanun Pembinaan Kehidupan Adat").

Pasal 1 angka 23 Qanun Lembaga Adat mendefinisikan Panglima Laot sebagai orang yang memimpin dan mengatur adat istiadat dalam bidang pesisir dan kelautan. Pengertian ini sangat umum, sehingga menimbulkan penafsiran bahwa Panglima Laot memiliki kekuasaan dan ortoritas yang sangat luas. Di samping sebagai wahana partisipasi masyarakat dalam penyelenggaraan pemerintahan dan pembangunan, Panglima Laot juga berfungsi sebagai lembaga pembinaan masyarakat dan penyelesaian masalah-masalah sosial yang terkait dengan hukum adat laut serta sebagai pelaksana hukum adat laut. Studi Wilson dan

29 Sulaiman Tripa, "Lembaga Hukum Adat Laot dan Peran yang Terus Berubah", dalam Adli, et.al (ed), Kearifan Lokal di Laut Aceh, (Banda Aceh: Syiah Kuala University Press, 2010), hal. 112, dan Kamaruzzaman, "Panglima Laot di Aceh Masa Kini: Sebuah Tinjauan Sosial-Antropologi", dalam Adli, et.al (ed), Kearifan Lokal di Laut Aceh, (Banda Aceh: Syiah Kuala University Press, 2010), hal. 5 . 
Linkie menyimpulkan lembaga adat Panglima Laout terbukti dapat menciptakan lingkungan yang memungkinkan terwujudnya partisipasi masyarakat. ${ }^{30}$ Oleh karena itu, dalam upaya merealisasikan penerapan prinsip partisipatif dalam pengelolaan sumber daya laut, penting untuk menjalin kerja sama dengan lembaga adat Panglima Laot.

Sementara itu, hukum adat adalah seperangkap ketentuan tidak tertulis yang hidup dan berkembang dalam masyarakat Aceh, yang memiliki sanksi apabila dilanggar. ${ }^{31}$ Sedangkan hukum adat laot adalah "hukum adat yang diberlakukan oleh masyarakat nelayan untuk menjaga ketertiban dalam penangkapan ikan dan kehidupan masyarakat nelayan di pantai." 32 Hukum adat laot memuat hak dan kewajiban yang muncul dalam kaitannya dengan kepemilikan wilayah laut. Namun demikian eksistensinya sangat beragam antara satu wilayah dengan wilayah lainnya karena sangat tergantung pada hukum yang hidup dalam masyarakat sebagai wujud dari kesepakatan sehingga hukum adat itu harus ditemukan. ${ }^{33}$

Walaupun pengertian hukum adat laot masih sangat umum akan tetapi bisa dipahami bahawa hukum adat laot adalah hukum yang hidup, berkembang dan dijalankan oleh masyarakat pesisir. Masyarakat tersebut memiliki karakteristik khas yang berbeda antara satu wilayah dengan wilayah lainnya. Salah satu contoh hukum adat laot yang telah dijalankan oleh masyarakat secara turun temurun bisa ditemukan pada masyarakat Ujong Pancu, Kecamatan Peukan Bada, Kabupaten Aceh Besar. Adapun hukum adat laot tersebut dituangkan dalam bentuk beberapa poin aturan dan larangan yang diantaranya: (1) larangan memancing di hari Jum'at dan hari besar (Hari Raya Idul Fitri dan Hari Raya Idul Adha, Festival Laut, hari peringatan tsunami 26 Desember, dan hari kemerdekaan 17 Agustus), hari-hari yang tidak hanya dianggap sebagai hari libur bagi nelayan dan kesempatan untuk memperbaiki kapal, tetapi juga dipercaya dapat memberi kesempatan bagi habitat laut untuk berkembang biak; (2) larangan membuang sampah dan sampah

30 Wilson \& Linkie, "The Panglima Laot of Aceh: a case study in large-scale community-based marine management after the 2004 India Ocean tsunami", Oryx, 46,(2012), hal. 495-500.

31 Pasal 1 Angka 28 Qanun Lembaga Adat, Op. Cit.

32 Rumusan dalam Musyawarah Panglima Laot se-Aceh, pada 6-7 Juni 2001 (Sulaiman Tripa, Model Kebijakan Pengelolaan Perikanan; belajar dari Masyarakat Lhok Rigaih Kabupaten Aceh Jaya, (Banda Aceh: Pusat Studi Hukom Adat Laot dan Kebijakan Perikanan Universitas Syiah Kuala, 2012), hal. 13.

33 Ibid, hal. 13-14. 
yang berupa ikan ke laut yang dikhawatirkan akan mempengaruhi kualitas terumbu karang; dan (3) larangan menggunakan alat tangkap yang tidak ramah lingkungan. ${ }^{34}$ Adanya larangan melaut pada hari perayaan tsunami pada 26 Desember, dimana sebelum aturan tersebut sebelum peristiwa tsunami 26 Desember 2004 belum ada, menandakan bahwa hukum adat itu juga berkembang dan mengikuti perkembangan masyarakat sehingga eksistensinya juga perlu terus dievaluasi dan dikritisi.

Pelanggaran terhadap ketentuan hukum adat laot memiliki konsekuensi dan Panglima Laot berperan dalam memastikan keberlangsungan dan kelestarian hukum adat laot. Keberadaan hukum adat laot juga di samping menekankan pada aspek ekologi juga pada aspek ekonomi. Dengan kata lain, adanya keseimbangan antara kepentingan ekonomi dan kepentingan pelestarian ekosistem laut, dan juga keseimbangan antara hubungan vertikal (hubungan dengan Tuhan sebagai pencipta alam semesta) dan hubungan horizontal (sesama manusia). ${ }^{35}$ Konsep tersebut menunjukkan bahwa dalam pelaksanaannya hukum adat laot telah menerapkan pengelolaan sumber daya laut yang berkelanjutan (sustainability) sehingga diharapkan kolaborasi antara kearifan lokal dan kebijakan pemerintah yang mengedepankan kepentingan masyarakat, berpotensi mewujudkan pengelolaan kawasan pesisir yang berkelanjutan.

\section{Implementasi Program Pengelolaan Pesisir Berbasis Masyarakat di Provinsi Aceh}

Pemerintah Aceh menginisiasi pelaksanaan Program Pengelolaan Wilayah Pesisir Berbasis Masyarakat (locally-managed marine areas) yang bertujuan untuk memperkuat peran masyarakat pesisir dalam pengelolaan dan perlindungan sumber daya laut secara berkeadilan dan berkelanjutan bekerjasama dengan Pemerintah Daerah. Pada tahun 2008, DKP Provinsi Aceh, sebagai leading sector pengelolaan dan perlindungan wilayah pesisir, membentuk Satuan Tugas Kelautan dan Perikanan (selanjutnya disebut "satuan tugas") yang bertujuan untuk

${ }^{34}$ Adli, "Model Hukum Adat Laot Menuju Keberlanjutan Lingkungan", dalam Adli, et.al (ed), Kearifan Lokal di Laut Aceh, (Banda Aceh: Syiah Kuala University Press, 2010), hal. 23.

35 Sulaiman Tripa, "Eksistensi Hukom Adat Laot Menuju Pengentasan Kemiskinan", (makalah dipresentasikan dalam Forum Rembug Nasional Mahasiswa Pascasarjana, Universitas Gajah Mada , Yogyakarta, 2009). 
mengembangkan jaringan kerja pengelolaan wilayah laut secara komprehensif dengan berdasarkan pada perlindungan keanekaragaman hayati dan mengakomodir keterlibatan dan aspirasi masyarakat. Sedangkan secara khusus, satuan tugas bertujuan untuk mengidentifikasi wilayah prioritas bagi konservasi keanekaragaman hayati laut (melalui systematic conservation planning) dan pelibatan masyarakat pesisir (melalui participatory planning) untuk menjalankan program tersebut.

Pada tahapan pelaksanaan, pihak dari DKP Provinsi mengadakan serangkaian lokakarya (workshop) dengan DKP dari 8 (delapan) Kabupaten/Kota yang menjadi prioritas area konservasi. Kegiatan ini bertujuan untuk memberikan pemahaman tentang program pengelolaan wilayah pesisir berbasis masyarakat dan pemahaman terkait metode analisa perencanaan secara sistematik (systematic planning analysis). ${ }^{36}$ Metode ini merupakan metode yang digunakan untuk menentukan daerah-daerah yang menjadi target konservasi. Penting adanya pemahaman yang komprehensif bagi petugas lapangan, yang merupakan pihak yang paling bertanggung jawab dalam pelaksanaan program, untuk menyebarluaskan pemahaman mengenai pentingnya program dan bagaimana melaksanakan program tersebut dalam masyarakat.

Tahapan selajutnya adalah mengadakan konsultasi publik pada tingkat kabupaten/kota dan desa dengan beberapa stakeholder terkait, diantaranya: masyarakat pesisir yang tinggal di kawasan yang menjadi target konservasi (diwakili oleh kepala desa dan/atau pimpinan adat), perwakilan kelompok nelayan termasuk Panglima Laot, perwakilan dari Dinas Kelautan dan Perikanan tingkat Provinsi dan Kabupaten/Kota, Pemerintah Kabupaten/Kota, dan stakeholder lainnya seperti kelompok perempuan dan pimpinan keagamaan. ${ }^{37}$ Konsultasi bertujuan untuk mendapatkan dukungan dari masyarakat dan menjadi langkah awal pelibatan masyarakat dalam perencanaan program.

Pasal 29 UU Pengelolaan Wilayah Pesisir menetapkan bahwa pola pengelolaan Kawasan Konservasi Pesisir dan Pulau-Pulau Kecil ("KKP3K") dilakukan dengan sistem zonasi, yaitu: (1) zona inti, merupakan bagian dari KKP3K yang dilindungi, yang ditujukan untuk perlindungan habitat dan populasi sumber daya P3K serta pemanfaatannya hanya terbatas untuk penelitian; (2) zona pemanfaatan

36 Syakur et. al, "Ensuring local stakeholder support for marine conservation: establishing a locally-managed marine area network in Aceh," Oryx, 46, (2012), hal. 519.

37 Ibid, hal. 519. 
terbatas, merupakan bagian dari zona konservasi P3K yang pemanfaatannya hanya boleh dilakukan untuk budidaya pesisir, ekowisata, dan perikanan tradisional; dan/atau (3) zona lain sesuai dengan peruntukkan kawasan.

Berdasarkan aturan tersebut, DKP Provinsi Aceh membagi Kawasan Konservasi Pesisir ("KKP"), yang salah satunya berada di kawasan Ujong Pancu, Aceh Besar ke dalam beberapa zona. Pertama, zona inti / zona pelindung (Lhok Talindong), zona ini dibenarkan untuk memancing selama kegiatan tidak merusak terumbu karang. Di zona ini, setiap orang dilarang melakukan pemboman dan pembiusan, menggunakan jaring pukat dan membuang jangkar, dan melakukan budidaya dan sejenisnya. Kedua, zona penyangga / perikanan berkelanjutan (Lhok Peulindong), zona ini berjarak 100 meter dari zona inti. Dalam zona ini, terdapat larangan pemboman dan pembiusan, penggunaan berbagai jenis jaring yang dapat merusak terumbu karang, serta penggunaan kompresor dan lampu merkuri. Ketiga, zona pemanfaatan (Lhok Teumanfaat) yang dimaksudkan untuk pukat darat tradisional (traditional trawl) dan pancing tradisional, serta daerah ekosistem bakau dan budidaya air tawar. Dalam zona ini juga terdapat larangan penggunaan bom dan obat bius, penembakan ikan di malam hari, dan penangkapan ikan di daerah pukat tanpa pengawasan.

Masyarakat juga berhasil menyepakati beberapa agenda, diantaranya kesepakat bahwa desain wilayah laut berbasis masyarakat harus mempertimbangkan faktor-faktor ekonomi, sosial, ekologi, keterwakilan habitat, dan luas wilayah. Konsultasi dan diskusi berakhir sampai akhirnya menghasilkan suatu peta untuk masing-masing wilayah dan aturan pengelolaan yang berhasil disepakati oleh semua pihak yang berkepentingan.

Di samping itu, program ini juga menyadari besarnya peran institusi adat Panglima Laot, yang mempunyai pengaruh yang sangat besar pada masyarakat pesisir di Aceh. Hal ini diperkuat dengan pengakuan keberadaan lembaga adat yang diatur dalam UU Pengelolaan Wilayah Pesisir, yang pada Pasal 28 ayat (3) huruf c mengatur bahwa kawasan konservasi mempunyai ciri khas sebagai satu kesatuan ekosistem diselenggarakan untuk melindungi wilayah yang diatur oleh adat termasuk panglima laot. Keikutsertaan institusi adat ini dengan hukum adat laotnya memberi pengaruh yang besar terhadap partisipasi masyarakat yang akhirnya diharapkan dapat menyukseskan pelaksanaan program. Selain itu, tahapan konsultasi yang intensif ini juga terbukti 
menjadi media untuk menyelesaikan sengketa, terutama terkait sengketa perbatasan dan tumpang tindih perbatasan. Kegiatan ini difasilitasi oleh Panglima Laot. ${ }^{38}$

\section{Pembahasan}

Perlindungan dan pengelolaan wilayah pesisir di Aceh dilakukan dengan dua pendekatan, yaitu pembentukan aturan hukum dan penguatan kapasitas institusi masyarakat, institusi adat dan hukum adat yang dipercaya dapat menjadi wadah yang efektif dalam keterlibatan masyarakat dalam proses pembangunan. Aceh memiliki potensi sistem pemerintahan dalam pengelolaan lingkungan, termasuk pengelolaan wilayah pesisir.

Keterlibatan masyarakat (community participation) dalam proses pembangunan dianggap penting dalam upaya untuk menghasilkan kebijakan yang efektif dan dapat dirasakan manfaatnya oleh masyarakat sebagai pihak penerima manfaat pembangunan. Konsep ini juga dipercaya dapat meminimalkan dampak negatif dari pembangunan. Selain itu, partisipasi masyarakat juga memberi kesempatan kepada masyarakat untuk memperoleh informasi yang berimbang dan obyektif, yang berkontribusi untuk pemecahan masalah dan meminimalkan konflik dalam pembangunan khususnya pembangunan masyarakat di wilayah pesisir.

Pengelolaan wilayah pesisir akan lebih efektif dilakukan dengan keterlibatan semua pihak yang berkepentingan. Hal ini disebabkan sifat dari wilayah pesisir yang tidak hanya memiliki fungsi ekologis tetapi juga fungsi sosial-ekonomi sehingga efektivitas manajemen perlindungan wilayah pesisir membutuhkan keterlibatan banyak pihak (governance system) dengan pendekatan yang multi-disiplin. Hal ini telah dicoba diwujudkan dalam program pengelolaan wilayah laut berbasis masyarakat di Aceh. Komunikasi intensif dengan pihak-pihak berkepentingan menjadi media yang diharapkan efektif mewadahi partisipasi masyarakat. Keterlibatan lembaga adat Panglima Laot, dan adat laot dapat semakin memperkuat peran masyarakat dalam proses pembangunan daerah pesisir. Kolaborasi antara stakeholders terkait

38 Wawancara, Syakur, Staff DKP Aceh (Pelaksana Program pemberdayaan masyarakat pesisir berbasis masyarakat 2010), 29 Oktober 2014. 
membentuk suatu sistem tata kelola yang saling mendukung proses kebijakan yang mewakili banyak kepentingan.

$\begin{array}{ccccc}\text { Program } & \text { pengelolaan } & \text { pesisir } & \text { berbasis } & \text { masyarakat } \\ \text { mengembangkan } & \text { pengelolaan } & \text { bersama } & \text { antara } & \text { pemerintah }\end{array}$
kabupaten/kota dan masyarakat. Program ini menempatkan masyarakat sebagai aktor utama dalam pelaksanaan program, dengan dukungan pemerintah kabupaten/kota. Pengembangan konsep ini dapat menjadi salah satu jawaban dalam upaya menerapkan tata kelola pemerintahan yang baik, yang tidak hanya menggambarkan demokrasi dalam pengambilan keputusan tetapi juga menggambarkan sistem jaringan antara pemerintah dan masyarakat. Sistem jaringan yang diharapkan menjadi proses penting untuk mengatasi kompleksitas dan tantangan yang dihadapi dalam upaya perlindungan dan pengelolaan lingkungan untuk mewujudkan pembangunan berkelanjutan.

Program co-management pengelolaan wilayah pesisir disamping memunculkan paradigma baru dalam pengelolaan wilayah pesisir juga menjadi media pengakuan terhadap keberadaan masyarakat adat dan hukum adat. Lebih lanjut juga dapat menjadi salah satu media penyelesaian konflik sosial dalam masyarakat, misalnya konflik terkait tumpang tindih perbatasan wilayah laut antara satu kabupaten/kota dengan yang lainnya. ${ }^{39}$

\section{Kesimpulan dan Rekomendasi}

Program pengelolaan pesisir berbasis masyarakat merupakan langkah nyata dalam mewujudkan partisipasi masyarakat. Walaupun sampai saat ini belum dilakukan evaluasi terhadap efektivitas program tersebut, tetapi sebagai langkah awal program tersebut telah menunjukkan adanya upaya untuk membentuk tata kelola yang baik dalam pengelolaan dan perlindungan daerah laut/pesisir. Langkah selanjutnya adalah bagaimana meyiapkan masyarakat untuk berperan lebih aktif dalam melindungi lingkungan laut tempat mereka menetap dan mencari kehidupan.

Meskipun penerapan kearifan lokal melalui kehadiran Panglima Laot menjadi salah satu perwujudan dari partisipasi masyarakat dalam program pengelolaan lingkungan, tetapi masih membutuhkan evaluasi yang lebih menyeluruh terkait dengan peran institusi adat tersebut

39 Wawancara, Syakur, Staff DKP Aceh (Pelaksana Program pemberdayaan masyarakat pesisir berbasis masyarakat 2010, 29 Oktober 2014. 
sejalan dengan perkembangan perannya di kalangan masyarakat nelayan di Aceh. Tantangan berikutnya adalah mengolaborasikan pendekatan pengelolaan partisipatif dengan pendekatan adat laot tersebut dalam pelaksanaannya sehingga program lebih efektif. Sekalipun demikian, evaluasi dan monitoring mengenai efektivitas program masih perlu dibuktikan melalui penelitian lebih lanjut dengan metodologi yang sesuai. Penilaian mengenai efektivitas program tersebut juga sangat terkait dengan keberlanjutan program dimana pada tahapan akhir diharapkan masyarakat dapat mengelola program tersebut secara mandiri.

Terkait hal tersebut, tulisan ini merekomendasikan Pemerintah Aceh melalui DKP untuk menginisiasi evaluasi terhadap Program Pengelolaan Wilayah Pesisir. Evaluasi perlu dilakukan untuk menilai efektivitas pelaksanaan program, termasuk memastikan apakah metode partisipasi masyarakat yang dilakukan efektif untuk menyelesaikan masalah terkait lingkungan di kawasan pesisir. Lebih lanjut, penilaian terhadap program perlu dilakukan untuk memastikan masyarakat siap berperan lebih aktif dalam melindungi lingkungan laut tempat mereka menetap dan mencari kehidupan.

\section{Daftar Pustaka}

A. Syakur dkk. "Ensuring local stakeholder support for marine conservation: establishing a locally-managed marine area network in Aceh", Oryx, 46, (2012): 516-524.

Aceh Ocean Coral, Formasi Terumbu Karang Aceh. http:/ / acehoceancoral.org/artikel/formasi-terumbu-karang-aceh, diakses pada 28 Februari 2014.

Adli, A. "Model Hukum Adat Laot Menuju Keberlanjutan Lingkungan", di dalam Kearifan Lokal di Laut Aceh, edited by Adli, et. Al, 23. Banda Aceh: Syiah Kuala University Press, 2010.

Aslin and Brown. Toward whole of Community Engagement: A Practical toolkit. Australia: Murray Darling Basin Commission, 2004.

Dakin, Susan. “Challenging Old Models of Knowledge and learning: New Perspective for Participation in Environmental Management and Planning", Environments, vol.31, No.1 (2003): 93-107. 
Johnston, Kim A. Community Engagement: A relational perspective, dalam Tebbutt, J dan Cregan, Kate (Editor), Proceeding Australia and New Zealand Communication Association Annual Conference: Communication, Civics, Industry. Melbourne Australia: La Trobe University, 2007.

Hudalah, D, Winarso, H, and Woltjer, J. "Policy networking as capacity building: An analysis of regional road development conflict in Indonesia", Planning Theory, vol. 9 (4), (2010): 315-332.

Juhola and Westerhoff, L. "Challenges of adaptation to climate change across multiple scales: A case study of network governance in two European countries", Environmental Science E Policy, vol. 14, (2011): 239-247.

Kamaruzzaman, Bustaman, A. "Panglima Laot di Aceh Masa Kini: Sebuah Tinjauan Sosial-Antropologi", di dalam Kearifan Lokal di Laut Aceh, edited by Adli, et al, 1-13. Banda Aceh: Syiah Kuala University Press, 2010.

Muhammad Akib. Politik Hukum Lingkungan: Dinamika dan Refleksinya dalam Produk Hukum Otonomi Daerah. Jakarta: RajaGrafindo Persada, 2012.

Oracion, Miller, Christie. "Marine Protected Areas for whom? Fisheries, tourism, and solidarity in Philippine community", Ocean and Coastal Management, vol. 48, (2005): 393-410.

Ostrom, E. 1999. "Self-governance and Forest Resources", Occasional paper no. 20, Centre for International Forestry Research, (1999): 1-15.

Reed, M, S. “Stakeholder Participation for Environmental Management: A Literature Review", Biological Conservation, vol. 141, (2008): 24172430.

Sarkissian, dkk. Kitchen Table Sustainability: Practical Recipes for Community Engagement with Sustainability. United Kingdom: Earthscan, 2009.

Sulaiman Tripa. Eksistensi Hukom Adat Laot Menuju Pengentasan Kemiskinan, Makalah dipresentasikan dalam Forum Rembug Nasional Mahasiswa Pascasarjana. Yogyakarta: Universitas Gajah Mada, 2009.

--------. 2010. Lembaga Hukum Adat Laot dan Peran yang Terus Berubah', di dalam Kearifan Lokal di Laut Aceh, edited by Adli, dkk, 95-122. Banda Aceh: Syiah Kuala University Press. 
Tullungan, Kussoy, and Crawford. Community Based Coastal Resources Management in Indonesia: North Sulawesi early stage experiences, Convention of Integrated Coastal Management Practitioners in the Philippines, 10-12 November 1998.

Warburton. A Passionate Dialogue: Community and Sustainable Development, 1998, dalam Warburton, Community and Sustainable Development: Participation in the future. United Kingdom: Earthscan, 1998.

Wilson \& Linkie. 2012. “The Panglima Laot of Aceh: a case study in largescale community-based marine management after the 2004 India Ocean tsunami", Oryx, 46, (2012): 495-500. 